\title{
A Whole-Cell Candida albicans Assay for the Detection of Inhibitors towards Fungal Cell Wall Synthesis and Assembly
}

\author{
David J. Frost*, Kim D. Brandt, David Cugier and Robert Goldman \\ Anti-Infective Research, Department 47M, Building AP9A, Abbott Laboratories, \\ Abbott Park, IL 60064-3500, U.S.A.
}

(Received for publication November 4, 1994)

\begin{abstract}
A whole-cell C. albicans screen was designed to identify novel inhibitors interacting with the synthesis, assembly and regulation of the fungal cell wall. C. albicans was grown in a paired broth assay in 96-well plates with natural product extracts or pure chemical compounds in the presence and absence of the osmotic stabilizer, sorbitol. Growth was visually examined over a 7-day period and scored into different growth categories. Positives from the sorbitol rescue were then examined under the microscope for morphological alterations and grouped into several morphological classes. Sorbitol protection and cell morphology were indicators of novel antifungal agents from natural product extracts and pure compounds.
\end{abstract}

Infections from Candida albicans and other fungi pose a serious risk to immunocompromised individuals. The current antifungal drugs are either toxic (amphotericin B) or fungistatic (azoles) and new compounds are actively being sought. The fungal cell wall serves as a protective barrier, prevents osmotic bursting from protoplast turgor pressure and confers shape. The wall is therefore essential for growth and viability of fungi in a hypotonic environment. The cell wall consists of many macromolecular components such as $\beta$-glucans, chitin, mannoproteins and other proteins ${ }^{1)}$. Once these constituents are synthesized they are not randomly assembled in the cell wall but probably interact with each other via a series of wall-associated enzymes performing cross-linking, branching and other functions. Many of the polymers and wall-assembly products are essential to the organism and enzymes that synthesize these constituents could be important antifungal targets.

The cell wall is dispensable if fungi are protected with an osmotic support under specific conditions. Protoplasts stabilized with osmo-protectants have been important biochemical tools for studying the fungal cell wall architecture $^{2)}$. In addition, osmotic stability has been used with $C$. albicans and other fungi to study mode of action of several antibiotics ${ }^{3,4}$. Aculeacin-treated C. albicans cells were viable if broth cultures were protected with sorbitol, but lysed if plated out on agar without an osmotic support. Although appropriate for biochemical characterizations, this osmotic fragility test would be cumbersome for antifungal screening. Several high throughput screens have been reported utilizing osmotic factors for the detection of cell wall-acting antifungals. Protoplast regeneration schemes utilizing Neurospora crassa temperature-sensitive osmotic mutant (os-1) have been described ${ }^{5,6)}$ while release of $\beta$-galactosidase activity from an osmotically-shocked Saccharomyces cerevisiae strain also detected cell wall agents ${ }^{7)}$. None of these assays were adapted to a pathogen and questions have been raised to the relevance of such screens ${ }^{8,9)}$.

We describe here a whole-cell $C$. albicans screen to identify inhibitors of fungal cell wall synthesis and assembly based on osmotic protection and morphological characteristics of cells. A paired broth assay was established in a 96-well plates with $C$. albicans using an osmotic support. Damage to essential cell wall components from antifungal agents will lyse cells in the absence of an osmo-protectant but cells will continue to grow if a suitable stabilizer is present in the medium. Positives are then examined under the microscope for morphological alterations. Cells treated with drugs that interfere with cell wall biosynthesis often have distinct morphological characteristics. The changes in morphology can suggest the possible target or mode of action of the inhibitor. Morphology of cells has been used as a method to detect novel antifungal inhibitors ${ }^{10,11)}$ but is laborious to use as the sole determinate in screening. Combining the rescue of growth with sorbitol and morphological characteristics of cells forms the basis of the Sorbitol Protection and Morphology (SPAM) assay which enables detection of cell wall-acting antifungal agents in a high throughput assay.

\section{Materials and Methods}

MIC values were determined using $C$. albicans $\mathrm{CCH}$ 442 in the standard broth microdilution procedure ${ }^{12)}$. Cells were inoculated to a final concentration of $2 \times 10^{3}$ 
organisms $/ \mathrm{ml}$ and grown in $1 \times$ Yeast Nitrogen Base (Difco) with $0.5 \%$ glucose and incubated at $30^{\circ} \mathrm{C}$. Duplicate plates containing test samples were prepared and one set contained $0.8 \mathrm{M}$ sorbitol as an osmotic support in the medium. Plates were read at 2 and 7 days. The final assay volume was $100 \mu \mathrm{l}$. The MIC for each antifungal compound or extract was read as the lowest concentration in which there was no detectable visible growth. For single point analysis, natural product extracts for high throughput screening were dissolved in $10 \mu 1$ of $35 \%$ DMSO prior to adding cells. C. albicans $\mathrm{CCH} 442$ is a clinical isolate from Cook County Hospital.

\section{Results and Discussion}

The standard microtiter dilution assay for MIC determination was conducted with and without sorbitol, a common osmotic protectant used in stabilizing fungal protoplasts $^{2)}$. Inhibitors of $\beta-(1,3)$ glucan biosynthesis (papulacandin B and lipopeptides) were easily identified in this assay (Table 1). After 2 days of growth the MIC were similar for both $+/-$ sorbitol treatments, but after 7 days the sorbitol protected cells grew slowly with certain treatments. The MIC without sorbitol was $1.0 \mu \mathrm{g} / \mathrm{ml}$ for papulacandin B whereas with sorbitol the MIC was $>250$ $\mu \mathrm{g} / \mathrm{ml}$. Sorbitol protected cells can grow in the presence of up to $800 \mu \mathrm{g} / \mathrm{ml}$ of papulacandin B or cilofungin before lysis occurs (data not shown). This is a very broad window of protection and indicates specificity of these compounds for cell wall targets in the organism. Fermentations of papulacandin B and echinocandin B producing cultures (Papularia sphaerosperma NRRL 8086 and $\mathrm{AB} 1435 \mathrm{~K}-51$, respectively) were positive in the microtiter dilution tests.

The protection of growth with sorbitol is not limited to $\beta$ - $(1,3)$ glucan synthesis inhibitors but can also be applied to inhibitors of synthesis of other cell wall polymers, and the mechanisms controlling cell wall synthesis. Calcofluor white and Congo red are agents that activate chitin synthesis and interfere with polymer assembly ${ }^{13,14)}$. After 7 days of incubation, cell growth was visible at $250 \mu \mathrm{g} / \mathrm{ml}$ of calcofluor in the presence of sorbitol, but in its absence the MIC was $7.8 \mu \mathrm{g} / \mathrm{ml}$. Geotrichum lactis also grew in the presence of calcofluor when sorbitol was present $^{13)}$. Although Nikkomycin $Z$ is a potent inhibitor of chitin synthesis, this compound is dependent on peptide transport ${ }^{15,16)}$ and had no effect in the YNB medium. Cell wall synthesis is regulated by signal transduction pathways. Protein kinase C (PKC), Bypass $\mathrm{C}$ Kinase (BCK), Mitogen-activated protein kinase kinase (MKK) and Mitogen-activated protein kinase (MPK) deletion mutants in yeast require an osmotic support for growth ${ }^{17,18}$ ). The MIC of staurosporine, a PKC inhibitor ${ }^{19)}$, was increased in the presence of sorbitol protected $C$. albicans cells. The sorbitol protection assay is therefore a broad spectrum screen

Table 1. Effect of antifungal agents in the presence and absence of sorbitol for the microtiter dilution broth assay .

\begin{tabular}{|c|c|c|c|c|c|}
\hline \multirow[b]{3}{*}{ Compound } & \multicolumn{4}{|c|}{$M \mid C(\mu g / m)$} & \multirow[b]{3}{*}{ Mode of action } \\
\hline & \multirow[b]{2}{*}{-Sorbitol } & 2 day reading & \multicolumn{2}{|c|}{7 day reading } & \\
\hline & & +Sorbitol & -Sorbitol & +Sorbitol & \\
\hline \multicolumn{6}{|l|}{ Pure Compounds } \\
\hline Papulacandin B & 1.0 & 1.0 & 2.0 & $>250$ & Glucan synthesis \\
\hline Echinocandin B & 3.9 & 3.9 & 7.8 & $>250$ & " \\
\hline Cilofungin & 1.0 & 1.0 & 1.5 & $>250$ & $"$ \\
\hline Amphotericin B & 1.0 & 1.0 & 1.0 & 1.0 & Ergosterol binding \\
\hline Miconazole & 3.9 & 7.8 & 3.9 & 7.8 & Ergosterol synthesis \\
\hline Nikkomycin Z & $>250$ & $>250$ & $>250$ & $>250$ & Chitin synthesis \\
\hline Calcofluor white & 7.8 & 125 & 7.8 & $>250$ & Chitin synthesis and assembly \\
\hline Congo red & 0.2 & 15.6 & 0.2 & 100 & $"$ \\
\hline Tunicamycin & 7.8 & 7.8 & 7.8 & 7.8 & Glycoprotein synthesis \\
\hline Brefeldin A & 250 & 250 & $>250$ & $>250$ & Secretory pathway \\
\hline Cycloheximide & $>250$ & $>250$ & $>250$ & $>250$ & Protein synthesis \\
\hline Actinomycin D & 250 & 125 & 250 & 125 & Nucleic acid synthesis \\
\hline Staurosporine & 0.2 & 0.2 & 15.6 & 125 & Protein kinase $\mathrm{C}(\mathrm{PKC})$ \\
\hline \multicolumn{6}{|l|}{ Natural product extracts } \\
\hline Papulacandin B producer & 61 & 61 & 121 & 3633 & Glucan synthesis \\
\hline Echinocandin B producer & 78 & 78 & 156 & 4265 & $"$ \\
\hline
\end{tabular}


that can find not only agents that directly affect cell wall synthesis and assembly but also regulatory mechanisms involved in this process. Agents whose mode of action is not associated with cell wall synthesis or that do interfere with the cell wall process but show nonspecific interactions with other unrelated targets will have limited protection with sorbitol.

The assay was adapted to a primary screen. Rather than conducting a microtiter dilution with each natural product extract, a one point concentration was used for each sample. Since the protection window with sorbitol was quite broad with papulacandin B or echinocandin $B$ producing fermentations, moderate concentrations of extracts could be used to increase the sensitivity of the assay. Plates are examined visually after 2 and 7 days and scored into various growth categories. Control cells were confluent in growth after 2 days in the absence of sorbitol. At 2 days of growth, all wells with antifungal activity in both the presence and absence of sorbitol are scored as "clear" indicating growth inhibition. Those extracts requiring sorbitol for cell growth are listed as "strong protection" whereas those cells enhanced in growth with sorbitol are listed as "marginal protection". The marginal category is generally restricted for those extracts in which the sorbitol protected cells are confluent in growth but the minus sorbitol treatment has only a few colonies. Those extracts showing growth in the absence of sorbitol but inhibition in the presence of sorbitol are ignored. Sorbitol causes a slight stress to cells and in the presence of some weak nonspecific cell wall inhibitors, cell growth can be inhibited. The plates are then read at 7 days but only the clear hits and previous positives are examined. Those cells that grow slowly after 7 days in both $+/-$ sorbitol are scored as "slow growth". In a screen of natural product extracts from randomly isolated fungi, actinomycetes, and plants, the hit rate was less than $0.5 \%(>10,000$ extracts tested). Positives can then be analyzed in a microtiter broth dilution assay to determine the relative potency and how broad the sorbitol protection window is with the extract.

The second part of the assay is to examine microscopically each hit and record the morphology of the cells. This can be done at the primary screen stage but preferable during the microtiter dilution assay. Fungal morphology has been used as a method for primary screening of novel antifungals, but is laborious requiring examination of many samples. Positives from sorbitol protection assay limits not only the number of samples Table 2 C. albicans morphology classes of sorbitol protected hits from natural product extracts
and some antifungal agents

\begin{tabular}{|c|c|}
\hline Morphology Classes & Possible Target \\
\hline Normal round individual cells ( $4-6 \mu \mathrm{m}$ diameter) & 1) Chitin assembly 13,14 ) \\
\hline (Calcofluor white or Congo red treatment) & 2) Polymer cross-linking, branching? \\
\hline Enlarged round cells ( $8-35 \mu \mathrm{m}$ diameter) & 1) $B-(1,3)$ glucan synthesis 20$)$ \\
\hline forming multicellular aggregates & 2) $B-(1,6)$ glucan synthesis 21,22$)$ \\
\hline (Papulacandin \& Echinocandin "like") & 3) Bud site selection 23,24) \\
\hline $\begin{array}{l}\text { Oblong cells with some cells enlarged ( } 10 \mu \mathrm{m} \\
\text { in length and } 5 \mu \mathrm{m} \text { in width). Some elongated } \\
\text { cells in a row. (Staurosporine "like") }\end{array}$ & 1) Protein kinase $C^{25)}$ \\
\hline $\begin{array}{l}\text { Chain of bulbous yeast cells } \\
\text { (Nikkomycin or Polyoxin "like") }\end{array}$ & 1) Chitin synthesis ${ }^{16)}$ \\
\hline Hyphal growth & 1) Signal transduction pathways ${ }^{26}$ ) \\
\hline $\begin{array}{l}\text { Small round cells forming multicellular } \\
\text { aggregates } \\
\text { (one-half the normal size) }\end{array}$ & 1) Unknown \\
\hline $\begin{array}{l}\text { Rosettes- One normal cell with many small } \\
\text { budding cells around the perimeter of the } \\
\text { mother cell }\end{array}$ & 1) Bud site selection 23,24) \\
\hline
\end{tabular}


but also restricts the type of hits to those that interact with the cell wall. Cells treated with drugs that interfere with cell wall biosynthesis often have distinct morphological characteristics. The changes in morphology can suggest the possible target of the inhibitor. For example, glucan synthesis inhibitors such as papulacandin B and lipopeptides often cause cells to become enlarged in size $^{3,20)}$ while nikkomycin-treated $C$. albicans cells have problems with septation and separation and appear as a string of bulbous cells ${ }^{16}$. So far, seven morphology classes have been found from testing natural product extracts and antifungal agents (Table 2). Although treatment of $S$. cerevisiae with either Calcofluor white or Congo red resulted in multicellular aggregates ${ }^{13)}$, C. albicans morphology appeared nomal. Typically, the morphology is the same in both the $+1-$ plates but differences have been noted with some extracts. Generally the best morphologies are seen at sub-MIC levels in both assays. The list of possible targets is based on morphological characteristics reported in the literature as well as from the morphology of known antifungal agents observed in this study. Not all the possible targets listed in Table 2 have been documented as requiring sorbitol for growth. Grouping hits into morphology classes also enables certain types to be further examined in dereplications assays and for biochemical study.

The SPAM assay is a broad spectrum screen that finds inhibitors of the synthesis, assembly and regulatory mechanisms of the fungal cell wall in C. albicans. The assay is compatible with a range of natural products extracts as well as pure chemicals.

\section{References}

1) Reiss, E.; V. M. Hearn, D. Poulain \& M. G. Shepherd: Structure and function of the fungal cell wall. J. Med. Vet. Mycology 30: 143 156, 1992

2) Sentandreu, R.; E. Herrero, M. V. Elorza, H. Rico \& J. PASTOR: Synthesis and assembly of wall polymers on regenerating yeast protoplast. Experientia Suppl. 46: $187 \sim 195,1983$

3) Yamaguchi, H.; T. Hiratani, K. Iwata, \& Y. YАмамото: Studies on the mechanism of antifungal action of aculeacin A. J. Antibiotics 35: 210 219, 1982

4) Varona, R.; P. Pe'rez \& A. Duran: Effect of papulacandin B on $\beta$-glucan synthesis in Schizosaccharomyces pombe. FEMS Microbiol. Letters 20: $243 \sim 247,1983$

5) Selitrennikoff, C. P.: Use of a temperature-sensitive, protoplast-forming Neurospora crassa strain for the detection of antifungal antibiotics. Antimicrob. Agents Chemother. 23: $757 \sim 765,1983$

6) KIrsch, D. \& M. H. LAI: A modified screen for the detection of cell wall-acting antifungal compounds. J. Antibiotics 39: $1620 \sim 1622,1986$
7) ZAworski, P. G. \& G. S. Gill: Use of Saccharomyces cerevisiae expressing $\beta$-galactosidase to screen for antimycotic agents directed against yeast cell wall biosynthesis and possible application to pathogenic fungi. Antimicrob. Agents Chemother. 34: 660 662, 1990

8) Ryley, J. \& K. BarketT-BeE: Screening for antifungal activity. In Emerging Targets in Antibacterial and Antifungal Chemotherapy. Ed., J. SUTCLIFFE and N. H. GeORgopapadaKoU, pp. 546 567, Chapman and Hall, New York, 1992

9) Tracz, J. S.: Glucan biosynthesis in fungi and its inhibition. In Emerging Targets in Antibacterial and Antifungal Chemotherapy. Ed., J. SutCliffe and N. H. Georgopapadakou, pp. 495 523, Chapman and Hall, New York, 1992

10) GunJI, S.; K. ARIMA \& T. BePpu: Screening of antifungal antibiotics according to activities inducing morphological abnormalities. Agric. Biol. Chem. 47: $2061 \sim 2069,1983$

11) Fukushima, Y.; Y. SAKagami \& S. Marumo; $\beta$-Glucan biosynthesis inhibitors isolated from fungi as hyphal malformation inducer. Bioorganic Medicinal Chem. Lett. 3: $1219 \sim 1222,1993$

12) Pfaller, M. A.; T. Gerarden, M. Yw \& R. P. Wenzel: Influence of in vitro susceptibility testing conditions on the anticandidal activity of LY121019. Diagn Microbiol. Infect. Dis. 11: 1 9, 1989

13) RONCERO, C. \& A. DURAN: Effect of calcofluor white and congo red on fungal cell wall morphogenesis: In vivo activation of chitin polymerization. J. Bact. 163: $1180 \sim 1185,1985$

14) Roncero, C.; M. H. Valdivieso, J. C. Ribas \& A. DURAN: Effect of calcofluor white on chitin synthases from Saccharomyces cerevisiae. J. Bact. 170: 1945 1949, 1988

15) Basrai, M. A.; H-L. Zhang, D. Miller, F. Naider \& J. M. BECKER: Toxicity of oxalysine and oxalysinecontaining peptides against Candida albicans: regulation of peptide transport by amino acids. J. Gen. Microbiol. 138: $2353 \sim 2362,1992$

16) Gooday, G. W.: Inhibition of chitin metabolism. In Biochemistry of Cell Walls and Membranes in Fungi. Ed., P. J. KuHn et al., pp. $61 \sim 79$, Springer-Verlag, Berlin, 1990

17) Blumer, K. J.; G. L. Johnson \& C. A. Lange-Carter: Mammalian mitogen-activated protein kinase kinase kinase (MEK K) can function in a yeast mitogen-activated protein kinase pathway downstream of protein kinase C. Proc. Natl. Acad. Sci. USA 91: 4925 4929, 1994

18) Irie, K.; M. TaKase, K. S. LeE, D. E. Levin, H. Araki, K. Matsumoto \& Y. Oshima: MKK1 and MKK2, which encode Saccharomyces cerevisiae mitogen-activated protein kinase-kinase homologs, function in the pathway mediated by protein kinase C. Mol. Cell. Biol. 13: 3076 3083, 1993

19) Tamaoki, T.; H. Nomoto, I. Takahashi, Y. Kato, M. Moromoto \& F. TомiтA: Staurosporine, a potent inhibitor of phospholipid $\mathrm{Ca}^{2+}$ dependent protein kinase. Biochem. Biophys. Res. Commun. 135: $397 \sim 402,1986$

20) Bozzola, J. J.; R. J. Mehta, L. J. Nisbet \& J. R. Valenta: The effect of aculecin A and papulacandin $B$ on morphology and cell wall ultrastructure in Candida albicans. Can. J. Microbiol. 30: $857 \sim 863,1984$ 
21) Meaden, P.; K. Hill, J. Wagner, D. Slipetz, S. S. SOMMER \& H. BuSSEY: The yeast KRE5 gene encodes a probable endoplasmic reticulum protein required for (1-6)- $\beta$-D-glucan synthesis and normal cell growth. Mol. Cell. Biol. 10: 3013 3019, 1991

22) Brown, J. L. \& H. Bussey: The yeast KRE9 gene encodes an $\mathrm{O}$ glycoprotein involved in cell surface $\beta$-glucan assembly. Mol. Cell. Biol. 13: 6346 6356, 1993

23) DruBIN, D.: Development of cell polarity in budding yeast. Cell 65: 1092 1996, 1991

24) Chant, J.; K. Corrado, J. R. Pringle \& I. Herskowitz: Yeast BUD5, encoding a putative GDP-GTP exchange fractor, is necessary for bud site selection and interacts with bud formation gene $B E M 1$. Cell 65: 1213 1224, 1991

25) Kobori, H.; T. Toda, H. Yaguchi, M. Toya, M. Yanagida \& M. Osum: Fission yeast protein kinase C gene homologues are required for protoplast regeneration: a functional link between cell wall formation and cell shape control. J. Cell Sci. 107: $1131 \sim 1136,1994$

26) Sabie, F. T. \& G. M. GADD: Effect of nucleosides and nucleotides and the relationship between cellular adenosine 3': 5'-cycle monophosphate (cyclic AMP) and germ tube formation in Candida albicans. Mycopathologia 119: $147 \sim 156,1992$ 